\title{
Fusion of the genes encoding Escherichia coli heat-stable enterotoxin b (STb) and the maltose-binding protein to obtain mature STb enterotoxin
}

\author{
Marc Bossé, ${ }^{1}$ Carina E. HaNdL, ${ }^{2}$ Louis-ANDRÉ LoRTiÉ, ${ }^{1}$ Josée HAReL ${ }^{1}$ \\ and J. DANIEl Dubreuil ${ }^{1 *}$ \\ ${ }^{1}$ Department of Pathology and Microbiology, Faculty of Veterinary Medicine, Montréal University, St-Hyacinthe, \\ Québec, Canada J2S 7C6 \\ ${ }^{2}$ Center for Biotechnology, Karolinska Institute, NOVUM, S-141 57 Huddinge, Sweden
}

(Received 19 August 1992; revised 26 October 1992; accepted 5 November 1992)

\begin{abstract}
The heat-stable enterotoxin b gene (est $B$ ) of Escherichia coli was fused to the gene for maltose-binding protein (malE). The est $B$ gene was cloned into the pMAL-p vector using PCR. The construct consists of the signal sequence of maltose-binding protein, which directs the export of the fusion protein to the periplasm, and the maltosebinding protein fused to the STb polypeptide. A sequence encoding a factor Xa cleavage site is present between $m a l E$ and $e s t B$. The fused genes are controlled by $\mathbf{P}_{\text {tac }}$, a strong inducible promoter. Following IPTG induction, the recombinant strain expressed a $47 \mathrm{kDa}$ protein, which was easily purified from osmotic shock fluid by using preparative electrophoresis and electroelution. Cleavage of the fusion protein with factor Xa generated the maltosebinding protein $(42 \mathrm{kDa})$ and a polypeptide of approximately $5 \mathrm{kDa}$, corresponding to the molecular mass of mature STb. A monospecific polyclonal rabbit antiserum raised against purified STb reacted in immunoblot with the fusion protein and the cleaved-off peptide. A positive response was observed when testing the osmotic shock fluid containing the fusion protein in a rat intestinal loop assay. On average, 3-4 mg of MBP-STb protein was recovered per litre of induced recombinant strain.
\end{abstract}

\section{Introduction}

To date, enterotoxigenic Escherichia coli (ETEC) strains of porcine origin have been reported to produce two types of proteinaceous heat-stable enterotoxins. STa is methanol-soluble and induces intestinal secretion in infant mice and neonatal pigs, whereas STb is methanolinsoluble and induces intestinal secretion in weaned and neonatal pigs but does not affect infant mice (Burgess et al., 1978; Weikel et al., 1986). Despite similarities in heat-stability and association with transposons, STa and STb are distinct toxins (So et al., 1979; So \& McCarthy, 1980; Lee et al., 1983; Hu et al., 1987). STb appears to be a significant contributor to swine diarrhoea; the est $B$ gene is the toxin gene most commonly found in association with ETEC of diseased swine (Mainil et al., 1986; Moon et al., 1986; Harel et al., 1991; Handl et al., 1992). In addition, diarrhoea has been induced in specific pathogen-free piglets by administration of $E$. coli strains

*Author for correspondence. Tel. (514) 7738521 ext. 433; fax (514) 7735633 . producing STb toxin alone (Picken et al., 1983; Fairbrother et al., 1989). The heat-stable enterotoxins reversibly alter normal intestinal homeostasis (Sack, 1975), causing intestinal secretion and diarrhoea (Betley et al., 1986; Weikel et al., 1986).

Research on the mode of action of STb toxin has been hampered due to a low level of toxin production by wildtype strains and lack of a convenient in vitro assay. Purification of the native toxin by our group allowed development of convenient and rapid assays for STb enterotoxin (Dubreuil et al., 1991; Lortie et al., $1991 a, b$ ). In fact, one test was sensitive enough to detect the toxin in stools of a specific pathogen free piglet infected with an STb-positive E. coli strain (Lortie et al., 1991 c). Recently, Fujii et al. (1991) reported the purification of STb by ammonium sulphate fractionation and successive column chromatographies from the culture supernatant of a strain harbouring the plasmid encoding the est $B$ gene.

The cloned and sequenced est $B$ gene (Lee et al., 1983; Picken et al., 1983), encodes a 71 amino acid polypeptide, including a 23 amino acid signal sequence (Kupersztoch et al., 1990). This toxin is found in the bacterial periplasm 
as an $8.1 \mathrm{kDa}$ precursor that is converted to and secreted as a $5.2 \mathrm{kDa}$ mature protein (Kupersztoch et al., 1990; Dubreuil et al., 1991; Fujii et al., 1991). The amino acid sequence determined by Kupersztoch et al. (1990) coincides fully with the 48 carboxy-terminal amino acids inferred from the DNA sequence. In the same study, serine at position 24 , was shown to be the amino terminus of mature STb. Spandau \& Lee (1987) suggested that est $B$ gene was regulated by a weak promoter, explaining why very little STb toxin is produced by wildtype strains.

Numerous studies have described genetic fusions with the est $B$ gene (Spandau \& Lee, 1987; Handl et al., 1988; Lawrence et al., 1990; Urban et al., 1990a,b). However, these fusions could not serve as a source of free and biologically active STb enterotoxin. Although STb could be purified from culture supernatants of a wild type strain and a strain containing a recombinant plasmid, these methods did not provide a convenient source of readily obtainable mature STb enterotoxin (Dubreuil et al., 1991; Fujii et al., 1991).

In this study, we describe a genetic construct between malE gene, coding for a maltose-binding protein (MBP), and $e s t B$. This genetic contruct is under the control of the strong promoter $\mathrm{P}_{\mathrm{tac}}$ and can thus be induced. Mature $\mathrm{ST}$ b molecule was obtained after specific cleavage of the fusion protein by using an Xa protease. Expression of the fusion protein and its biological properties were also analysed. The MBP-STb hybrid protein is a readily obtainable source of active STb enterotoxin.

\section{Methods}

Strains and plasmids. The recombinant plasmid pRAS1 (Lee et al., 1983 ) was used to amplify the est $B$ gene. Plasmid constructs were cloned into strain HB101. The vector pMAL-p was purchased from New England Biolabs. The pMAL-p plasmid harbours a gene ( $m a l E$ ) coding for maltose-binding protein (MBP) controlled by a strong inducible promoter $\mathrm{P}_{\text {tac }}$ (Duplay et al., 1984; Maina et al., 1988). A polycloning site permits subcloning of a foreign gene at the $3^{\prime}$ end of malE. A sequence specific for factor $\mathrm{Xa}$ (a proteolytic enzyme) is present between malE and the fused gene.

DNA manipulations. Plasmid isolation was done by using the alkaline lysis method and plasmid DNA was purified by using ultracentrifugation in a caesium chloride gradient (Maniatis et al., 1982). The restriction enzymes $B g I I I, H i n d I I I, S t u I, X b a I$, T4 ligase, and mung bean nuclease were purchased from Pharmacia and used according to the manufacturer's recommendations. The pMAL-STb DNA construct was sequenced using the T7 Sequencing kit (Pharmacia). The estB PCR product used as a DNA probe was purified on acrylamide gel, eluted as described by Maniatis et al. (1982) and labelled by the random priming method using nanomers and T7 DNA polymerase (T7 Quickprime labelling kit, Pharmacia). Clones were screened by colony hybridization using an est $B$ PCR product. DNA hybridization was done according to the method of Lortie et al. (1991 a). The radioactive isotopes used were $\left[\alpha-{ }^{32} \mathrm{P}\right] \mathrm{dCTP}\left[3000 \mathrm{Ci}(111 \mathrm{TBq}) \mathrm{mmol}^{-1}\right]$ and $\left[\alpha^{-35} \mathrm{~S}\right] \mathrm{dATP}[500 \mathrm{Ci}$ (18.5 TBq) $\mathrm{mmol}^{-1}$ ] (New England Nuclear Research). Electrotransformations of recombinant plasmids were done with a Gene Pulser (BioRad) following the manufacturer's protocol.

Polymerase chain reaction (PCR) for subcloning. The DNA sequence coding for the mature STb protein was amplified enzymically. Oligonucleotides were designed with specific restriction site sequences to allow unidirectional subcloning into pMAL-p. The restriction sites $X b a \mathrm{I}$ and $H$ indIII were added to the $5^{\prime}$ and $3^{\prime}$ ends of the est $B$ gene, respectively. The $X b a \mathrm{I}$ restriction site sequence was added at the $5^{\prime}$ end of the oligonucleotide SXF (5'GCCTCTAGAGTACACAATCAAATAAAAA3') that hybridized specifically to the nucleotides 516-532 of estB according to Lee et al. (1983). The oligonucleotide SHR (5'TGTATAAGCTTCTGAATGCTATTG3') hybridized specifically to nucleotides 669-693 and the SHR oligonucleotide included nucleotide mismatches in order to create an HindIII restriction site. Amplification, at low stringency, was performed as described previously (Lortie et al., 1991 a) with the following changes: 5 cycles of denaturation steps at $94{ }^{\circ} \mathrm{C}$ for $30 \mathrm{~s}$, an annealing step at $40^{\circ} \mathrm{C}$ for $30 \mathrm{~s}$, and a synthesis step at $72^{\circ} \mathrm{C}$ for $1 \mathrm{~min}$. Twenty-five cycles were done at higher stringency using the following cycle: $94^{\circ} \mathrm{C}$ for $30 \mathrm{~s}, 60^{\circ} \mathrm{C}$ for $30 \mathrm{~s}, 70^{\circ} \mathrm{C}$ for $1 \mathrm{~min}$. The reaction was completed at $72^{\circ} \mathrm{C}$ for $7 \mathrm{~min}$. The reaction mix contained $50 \mathrm{~mm}-\mathrm{KCl}, 1.5 \mathrm{~mm}-\mathrm{MgCl}_{2}, 10 \mathrm{~mm}-\mathrm{Tris} /$ $\mathrm{HCl}(\mathrm{pH} 8 \cdot 3), 12 \cdot 5 \mu \mathrm{M}-\mathrm{NTPs}, 100 \mathrm{pmol}$ SXF and SHR respectively, 0.3 pmol pRAS target DNA and 0.5 units Taq polymerase in $100 \mu \mathrm{l}$ volume. After amplification, the DNA was immediately phenol/ chloroform-extracted and ethanol-precipitated. The DNA was thereafter resuspended in $20 \mu 10 \mathrm{~mm}-\mathrm{Tris} / \mathrm{HCl}(\mathrm{pH} 8.0)$ containing $1 \mathrm{~mm}$ EDTA. Oligonucleotides were synthesized by Bio-Synthesis. The enzymic DNA amplification was performed on a DNA Thermal Cycler model 480 using the Geneamp kit (Perkin Elmer Cetus).

Immunocolony screening. Clones were inoculated on Luria Broth agar medium containing $50 \mu \mathrm{g}$ ampicillin $\mathrm{ml}^{-1}$ and $0.3 \mathrm{mM}$-IPTG (Sigma) and incubated for $4 \mathrm{~h}$ at $37^{\circ} \mathrm{C}$. Cells were then lysed by chloroform treatment and transferred onto cellulose filters (Schleicher $\&$ Schuell). The conditions used for immunological reactions were identical to the Western blot protocol described below. pMAL-STb clones were screened immunologically with anti-STb antibodies (Dubreuil et al., 1991).

Electrophoresis. SDS-PAGE was done according to Laemmli (1970) in a Mini-slab apparatus (BioRad). Total cell extract or purified protein solubilized in sample buffer was stacked in a $4.5 \%(\mathrm{w} / \mathrm{v})$ acrylamide gel $(100 \mathrm{~V}$, constant voltage) and separated on a $10 \%(\mathrm{w} / \mathrm{v})$ acrylamide gel $(200 \mathrm{~V})$. Low molecular mass proteins were analysed using the PhastSystem (Pharmacia) and high density SDS-PAGE PhastGel system according to the manufacturer's instructions. Proteins were stained with Coomassie Blue R-250. Gels were scanned using a LKB Ultroscan XL enhancer laser densitometer (LKB) to evaluate the relative amount of the fusion protein present in the osmotic shock fluid (OSF).

Immunoblotting. When required, proteins were transferred from slab gels to nitrocellulose paper using the methanol/Tris/glycine system described by Towbin et al. (1979). Electroblotting was done in a Hoefer transblot apparatus for $45 \mathrm{~min}$ at $100 \mathrm{~V}$. All incubations were at room temperature unless otherwise stated. Membranes were blocked with $20 \mathrm{~mm}$-Tris $/ \mathrm{HCl}$ (pH 7.5), $0.5 \mathrm{M}-\mathrm{NaCl}$ (TBS) to which $9 \%$ (w/v) skim milk was added. Primary antibodies were incubated for $12-16 \mathrm{~h}$ at $4{ }^{\circ} \mathrm{C}$. The polyclonal rabbit anti-STb antibodies were diluted $1: 100$ and the polyclonal anti-MBP antibodies 1:10000 in TBS containing 2\% $(\mathrm{w} / \mathrm{v})$ skim milk. Peroxidase-conjugated goat anti-rabbit $\operatorname{IgG}(\mathrm{H}+\mathrm{L})$ (Jackson Immunoresearch) diluted 1:500 in TBS containing 2\% (w/v) skim milk was incubated for $1 \mathrm{~h}$ at $4{ }^{\circ} \mathrm{C}$. Reactive bands were visualized 
by the addition of $0 \cdot 3 \%$ 4-chloro-1-naphthol (Sigma) in cold methanol and $0.06 \% \mathrm{H}_{2} \mathrm{O}_{2}$ in Tris/saline (Hawkes, 1982). Prestained SDSPAGE low range markers (BioRad) and peptide molecular mass markers (Pharmacia) were used.

For detection of STb peptide, Immunodyne membrane (Pall Biosupport Division) was precut to convenient sizes and layered on top of prerun PhastGels using the PhastSystem (Pharmacia). Protein transfer was done by passive diffusion at $65^{\circ} \mathrm{C}$ by overlaying the membrane with a pile of filter paper and a heavy weight. After transferring for $30 \mathrm{~min}$ the membrane was blocked for $30 \mathrm{~min}$ in $5 \%$ $(\mathrm{w} / \mathrm{v})$ skim milk in phosphate-buffered saline (PBS; $10 \mathrm{mM}, \mathrm{pH} 7 \cdot 4$ ). Rabbit sera against protein A-STb fusion (Handl et al., 1988) was added to the blocking solution $(1: 500)$ and incubated for $2 \mathrm{~h}$. Membranes were washed 3 times for 5 min with PBST (PBS containing $0.1 \%$ Tween 20), incubated for $1 \mathrm{~h}$ with alkaline-phosphataseconjugated goat anti-rabbit IgG antibodies (Sigma) $(1: 4000)$, washed 3 times for 5 min with PBST and 2 min with $\mathrm{H}_{2} \mathrm{O}$ and thereafter developed. The reactive bands were visualized as described by Blake et al. (1984) with 5-bromo-4-chloro-3-indolyl phosphate (Boehringer) as the alkaline phosphate substrate and nitro blue tetrazolium (Boehringer) as the colour development reagent.

Immunodotting. A Bio-Dot microfiltration apparatus (BioRad) was used according to the manufacturer's protocol for immunodot analysis of samples. Samples were applied in the wells to the Immunodyne membrane, incubated for 30 min and then carefully sucked out. After rinsing wells with $200 \mu \mathrm{l}$ PBS the membrane was dried and immunostained according to above description for STb immunoblotting.

Purification of the fusion protein. An $18 \mathrm{~h}$ culture of the pMAL-STb clone was diluted 100 times in 1 litre rich medium (per litre: $10 \mathrm{~g}$ tryptone, $5 \mathrm{~g}$ yeast extract, $5 \mathrm{~g} \mathrm{NaCl}$ and $50 \mu \mathrm{g}$ ampicillin $\mathrm{ml}^{-1}$ ) and kept at $37^{\circ} \mathrm{C}$. To induce expression of the fusion protein, IPTG was added to a final concentration of $0.3 \mathrm{~mm}$ when the $\mathrm{OD}_{600}$ reached 0.4 . Three hours after induction, cells were harvested by centrifugation at $4000 \mathrm{~g}$ for $10 \mathrm{~min}$ at $4{ }^{\circ} \mathrm{C}$. Cells were gently washed with $250 \mathrm{ml} 30 \mathrm{mM}$ Tris/ $\mathrm{HCl}(\mathrm{pH} 80$ ), containing $20 \%(\mathrm{w} / \mathrm{v})$ sucrose and 1 mM-EDTA. After centrifugation at $8000 \mathrm{~g}$ for 10 min at $4{ }^{\circ} \mathrm{C}$, cells were suspended in $250 \mathrm{ml} 5 \mathrm{~mm}-\mathrm{MgSO}_{4}$ at $4{ }^{\circ} \mathrm{C}$ for $10 \mathrm{~min}$. Following further centrifugation at $8000 \mathrm{~g}$ for $10 \mathrm{~min}$ at $4{ }^{\circ} \mathrm{C}$, the supernatant representing the osmotic shock fluid (OSF) was filter sterilized $(0.20 \mu \mathrm{m})$ and lyophilized.

Lyophilized OSF was reconstituted in sample buffer (Laemmli, 1970) to 10 times the original concentration, loaded on to $12.5 \%(\mathrm{w} / \mathrm{v})$ polyacrylamide gels $(12 \times 10 \times 0.22 \mathrm{~cm})$ and run at $100 \mathrm{~V}$ for $45 \mathrm{~min}$ followed by $200 \mathrm{~V}$ for $3.5 \mathrm{~h}$. After migration, a small part of the gel containing the sample and the molecular mass markers was Coomassiestained. The protein band at $47 \mathrm{kDa}$ was excised, minced, and electroeluted using an electroeluter Model 422 (BioRad). The electroelution was performed at $25 \mathrm{~mA}$ per glass tube for $6 \mathrm{~h}$ at $4{ }^{\circ} \mathrm{C}$ in $50 \mathrm{~mm}$ $\mathrm{NH}_{4} \mathrm{HCO}_{3}$ buffer using membrane caps with a $14 \mathrm{kDa}$ cut-off. Electroeluted material was dried by using a Speedvac evaporator. The fusion protein was desalted on a Fast Desalting Column HR 10/10 (FPLC Systems, Pharmacia) and fractions were analysed for STb by immunodot. The exclusion limit of the column was $5 \mathrm{kDa}$. The column was equilibrated with $\mathrm{Xa}$ enzyme buffer $(20 \mathrm{mM}-\mathrm{Tris} / \mathrm{HCl}$ (pH 8.0), $100 \mathrm{~mm}-\mathrm{NaCl}, 2 \mathrm{~mm}-\mathrm{CaCl}_{2}, 1 \mathrm{~mm}-\mathrm{NaN}_{3}$ ) diluted 20 times. The eluted material was then concentrated 20 times. Twenty microlitres $(0.3 \mathrm{mg}$ $\mathrm{ml}^{-1}$ ) of recovered MBP-STb was cleaved with $1 \mu \mathrm{l}$ containing $1 \mathrm{U}$ of $\mathrm{Xa}$ enzyme (New England BioLabs) for $3 \mathrm{~h}$ at room temperature. Samples were analysed on high density SDS-PAGE PhastGel.

Rat intestinal loop assay. The rat intestinal loop assay was performed as described previously (Dubreuil et al., 1991). Briefly, 6-to-8-week-old white rats (Sprague Dawley, C.D.) were used. The animals were fasted for $48 \mathrm{~h}$, anesthesized, and the abdomen was cut following a midline incision. The small intestine of the rat was located. A volume of $8 \mathrm{ml}$ of $20 \mathrm{~mm}$-Tris $/ \mathrm{HCl}$ (pH 6.8) plus $300 \mu \mathrm{g}$ soybean trypsin inhibitor (Boehringer) was injected into the small intestine and left for $5 \mathrm{~min}$. The liquid was then massaged and removed through the posterior end of the small intestine. A total of 8 loops ( $5 \mathrm{~cm}$ in length) were made and $0.5 \mathrm{ml}$ of sample was injected into each loop. After $4 \mathrm{~h}$ of incubation, the rat was killed, and the volume (ml) and the length (cm) of each loop were measured. Results were expressed as volume of liquid $(\mathrm{ml})$ per length $(\mathrm{cm}) \times$ circumference $(\mathrm{cm})$ of intestine and were considered positive if greater than $0 \cdot 05$. Each sample was tested at least 4 times in loops at different positions of the small intestine.

\section{Results}

This study involved the construction of hybrid plasmids to overexpress Escherichia coli heat-stable enterotoxin type $b(\mathrm{ST} b)$. A sequence coding for a Xa cleavage site was located at the $\mathrm{N}$-terminus of the mature $\mathrm{STb}$ protein. Specific cleavage of the maltose-binding protein (MBP)$\mathrm{STb}$ fusion molecule with the $\mathrm{Xa}$ enzyme generated mature STb toxin. A two-step strategy was used to clone est $B$ into pMAL-p. An intermediate clone pMAL-IN, where $e s t B$ is not in the same translational reading frame as the vector malE gene, was first generated. In the final construct pMAL-STb, which was derived from pMALIN, the same translational reading frame was established for both est $B$ and malE.

The est $B$ gene obtained from plasmid pRAS1 was inserted into the pMAL-p vector by using PCR. The PCR product was subcloned into the $X b a \mathrm{I}$ and HindIII polylinker restriction sites of the vector (Fig. 1). Clones were screened by colony hybridization using the est $B$ PCR product as a probe. The intermediate clone pMALIN did not express mature STb, since est $B$ was subcloned out of frame with malE. pMAL-IN was characterized by using the restriction enzymes $X b a \mathrm{I}, H i n d I I I$ and $B g I I I$. $B g / \mathrm{II}$ digestion of pMAL-IN generated an $800 \mathrm{bp}$ fragment corresponding to the $B g l \mathrm{II}$ restriction sites in the malE gene and the inserted est $B$ PCR product. The pMAL-IN clone produced a $45 \cdot 2 \mathrm{kDa}$ fusion protein consisting of $\mathrm{MBP}(42 \mathrm{kDa})$ and a $3.2 \mathrm{kDa}$ peptide. Strain HB101 harbouring pMAL-IN reacted with antiMBP polyclonal antibodies in immunoblot (Fig. $2 b$, lane 4). This polypeptide was coded by a sequence starting at the $X b a \mathrm{I}$ site of the polylinker, and the est $B$ gene was read out of frame until a stop codon was reached. The fusion protein produced by pMAL-IN did not react in immunoblot with anti-STb rabbit polyclonal antibodies (Fig. 2a, lane 4).

The final construct, named pMAL-STb, was derived from the intermediate clone pMAL-IN (Fig. 1). In order to create a MBP-STb fusion protein where the factor $\mathrm{Xa}$ cleavage site is located at the $\mathrm{N}$-terminal amino acid (serine 24) of mature STb, pMAL-IN plasmid was digested by $X b a I$ and blunt ends were generated with mung bean nuclease. The recombinant plasmid was then 

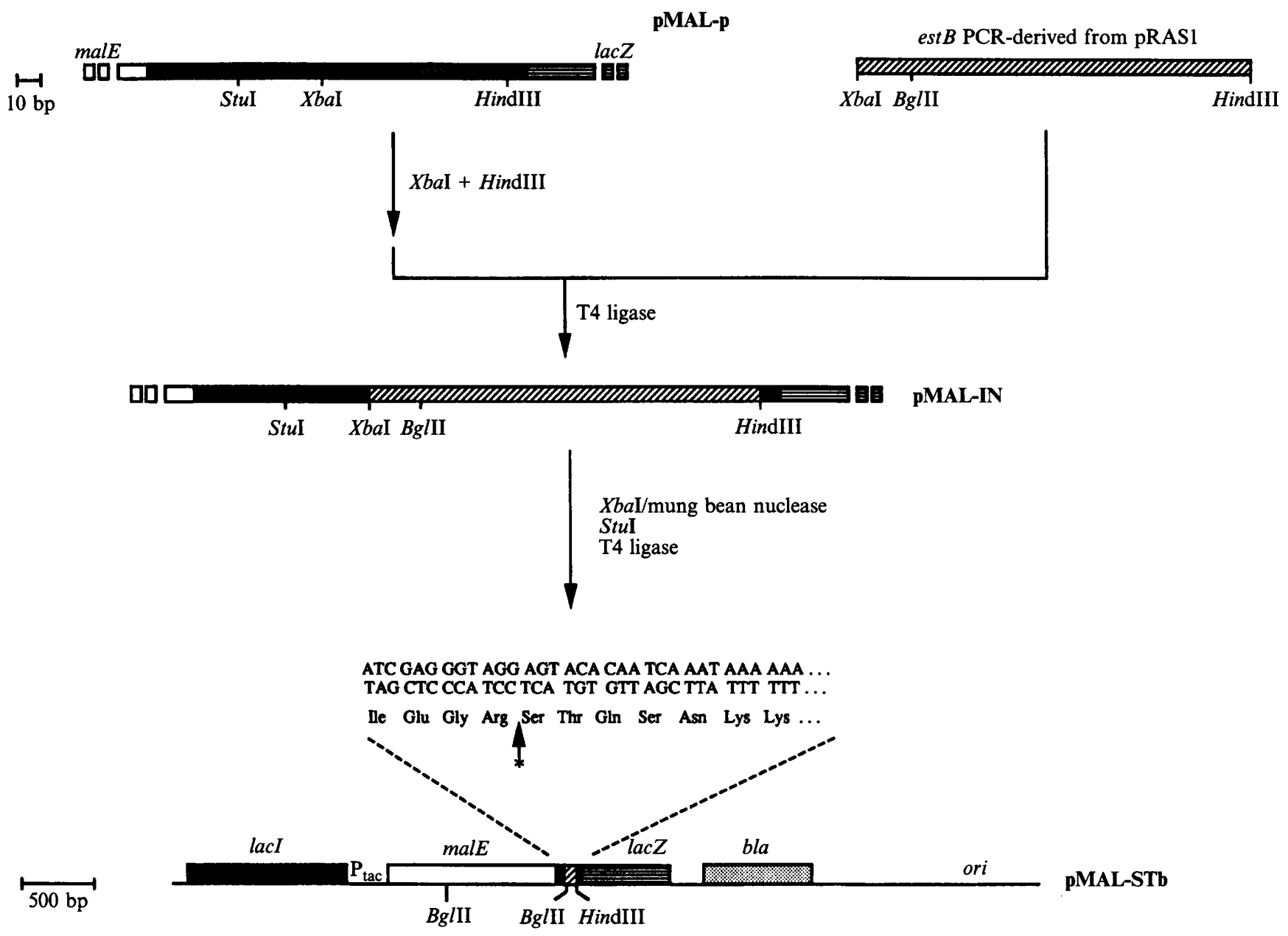

Fig. 1. Construction of plasmids pMAL-IN and pMAL-STb. Subcloning procedure for inserting est $B$ into the pMAL-p vector. The est $B$ gene was cloned into the $X b a I$ and $H$ indIII restriction sites of the pMAL-p polylinker. The pMAL-IN subclone was digested with $X b a I$ and treated with mung bean nuclease. The DNA was then digested with StuI and ligated. Final subclones were screened with polyclonal anti-STb antibodies. *, Xa factor cleavage site.

digested with $S t u I$, ligated, and electrotransformed into strain HB101 (Fig. 1). Clones expressing the MBP-STb fusion protein were screened immunologically with anti$\mathrm{STb}$ polyclonal antibodies. A positive clone was selected and named pMAL-STb. The malE-est $B$ construct was sequenced. The sequence determined for est $B$ was present in the right orientation and in its integrity (Lee et al., 1983). The est $B$ gene coding for mature STb toxin was cloned downstream of the malE gene and its signal sequence. The pMAL-p vector carried a sequence coding for a factor Xa cleavage site, situated at the $5^{\prime}$ end to the polylinker insertion sites, to create an MBP-STb fusion protein where the Xa cleavage site is located at the $\mathrm{N}$ terminus of STb.

In this construct, the fused genes are controlled by the strong inducible $P_{\text {tac }}$ promoter. After induction of $P_{\text {tac }}$ by addition of IPTG, the final product of the PMAL-STb construct was detected immunologically as a MBP-STb fusion protein of $47 \mathrm{kDa}$ (Fig. $2 a$ and $b$, lanes 6, 7). The MBP-STb protein was detected in total cell extract and in osmotic shock fluid, and reacted with anti-STb polyclonal antibodies (Fig. $2 a$, lanes 6,7 ). In noninduced total cell extract, a faint band was observed at the same level as the MBP-STb fusion protein indicating a weak transcription of malE-est $B$ even in the absence of induction (Fig. $2 a$, lane 5). The MBP-STb fusion protein was neither detected in strain HB101 nor in HB101 harbouring pMAL-IN (Fig. $2 a$, lanes 1, 2). The MBP$\mathrm{STb}$ protein reacted with anti-MBP polyclonal antibodies, but the native MBP was barely detected in strain HB101 (Fig. 2b, lanes 1, 2).

The amount of MBP-STb protein produced by the pMAL-STb harbouring strain was evaluated after IPTG induction at various times. Increasing amounts of MBP$\mathrm{STb}$ protein were observed up to $3 \mathrm{~h}$ after induction (Fig. 3 , lanes 1 to 6). Longer induction of pMAL-STb did not 


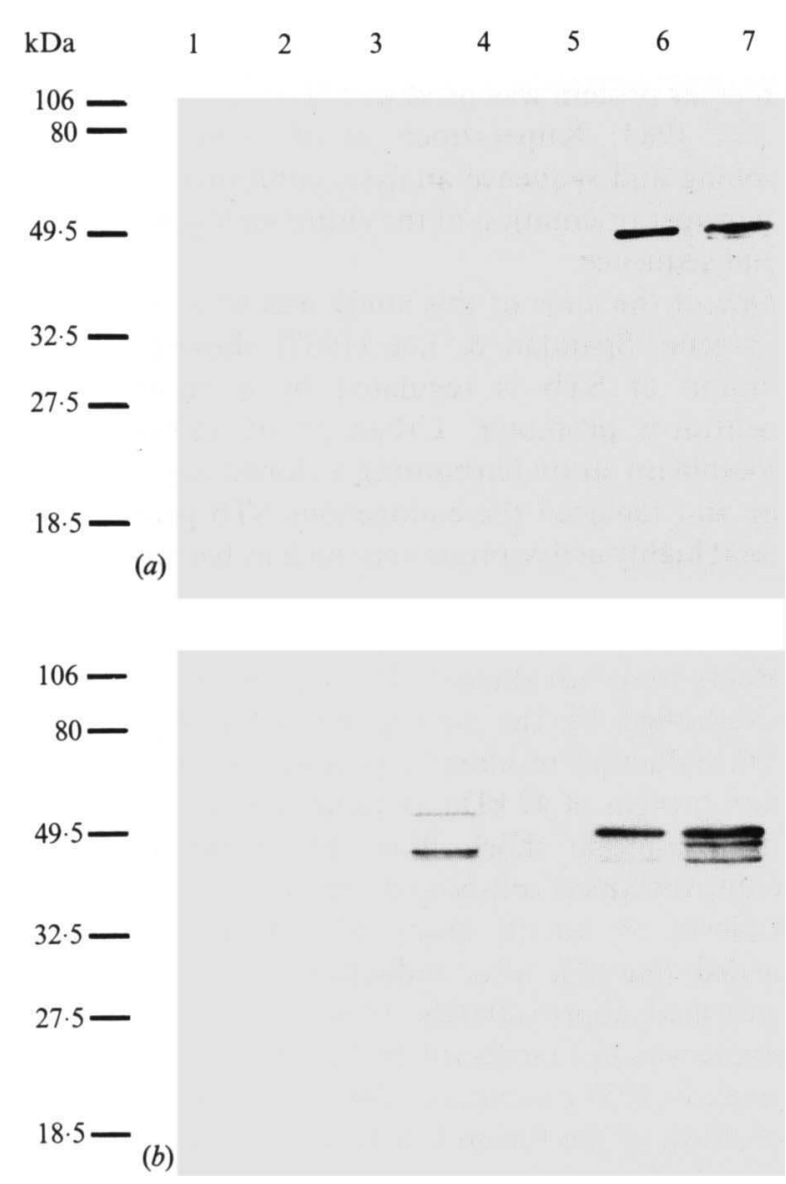

Fig. 2. Analysis of the MBP-STb fusion protein. (a) Immunoblot of total cell extracts using the anti-STb polyclonal antibodies of noninduced and induced cells. Lanes: 1, 2, total cell extracts of strain HB101, non-induced and induced, respectively; 3,4 , total cell extracts of pMAL-IN, non-induced and induced, respectively; 5, 6, total cell extracts of pMAL-STb, non-induced and induced, respectively; 7, osmotic shock fluid containing MBP-STb. Cells were grown at $37^{\circ} \mathrm{C}$ in rich medium to $\mathrm{OD}_{600}=0.4$ and induced for $3 \mathrm{~h}$ with $0.3 \mathrm{mM}$-IPTG. (b) Immunoblot identical to that shown in (a) but using anti-MBP polyclonal antibodies. Molecular mass standards to the left of the gel.

increase the amount of MBP-STb produced. Three hours after IPTG induction, the MBP-STb fusion protein was the most abundant periplasmic component, constituting approximately $33 \%$ of total protein in the OSF as detected by gel scanning. On average, 1 litre of induced HB101 strain harbouring pMAL-STb yielded 3-4 mg MBP-STb protein in the OSF. STb comprises about $1 / 10$ of the weight of the fusion protein and thus about $0.3-0.4 \mathrm{mg}$ of STb toxin is present in 1 litre. MBP-STb fusion protein was purified from other components of the OSF by preparative electrophoresis using $12.5 \%$ $(\mathrm{w} / \mathrm{v})$ polyacrylamide gel and electroelution. OSF preparations containing MBP-STb protein were biologically active in the rat intestinal loop assay (Table 1). OSF was desalted on a Fast Desalting Column HR 10/10. When

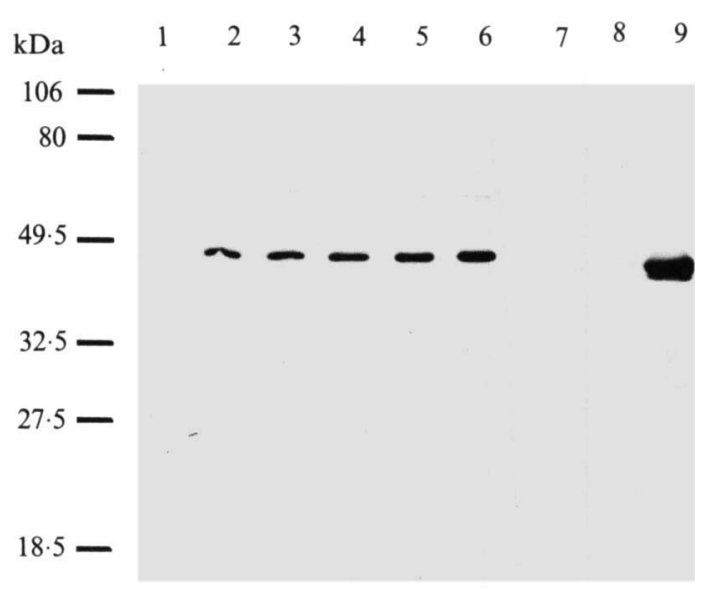

Fig. 3. Kinetic study of induction of MBP-STb fusion protein. Immunoblot using anti-STb polyclonal antibodies. Lanes: 1 to 6 , total cell extracts of pMAL-STb at $0,30,60,90,120$ and 180 min after induction with IPTG, respectively; 7, 8 and 9, osmotic shock fluids 180 min after induction with IPTG from strain HB101, strain HB101 harbouring pMAL-p and strain HB101 harbouring pMAL-STb, respectively. Molecular mass standards to the left of the gel.

Table 1. Biological activity in intestinal rat loop

Figures are means \pm SD of at least six determinations.

\begin{tabular}{llr}
\hline \multicolumn{1}{c}{ Strain } & \multicolumn{1}{c}{ Sample } & \multicolumn{1}{c}{$\begin{array}{c}\text { Ratio } \\
( \pm \text { SD })\end{array}$} \\
\hline HB101 & Supernatant & $0.04 \pm 0.00$ \\
HB101 (pRAS1) & Supernatant & $0.13 \pm 0.01$ \\
HB101 (pMAL-p) & OSF & $0.00 \pm 0.00$ \\
HB101 (pMAL-STb) & OSF & $0.125 \pm 0.08$ \\
\hline
\end{tabular}

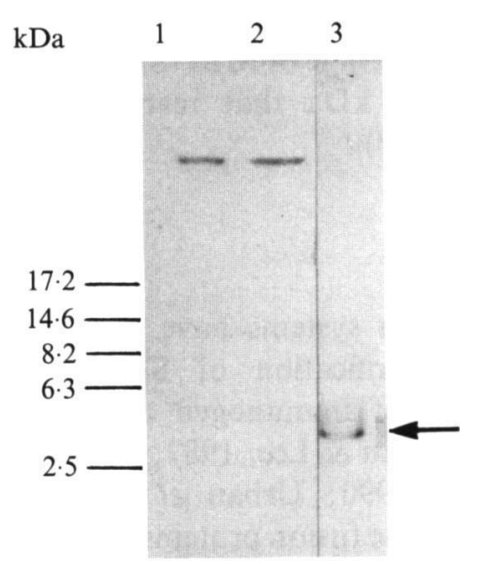

Fig. 4. MBP-STb fusion protein cleavage with Xa factor. Immunoblot using anti-STb polyclonal antibodies. Lanes: 1 , osmotic shock fluid from pMAL-STb clone; 2 , purified MBP-STb fusion protein; 3, MBP$\mathrm{STb}$ fusion protein purified and cleaved with factor $\mathrm{Xa}$. The arrow indicates STb polypeptide released by cleavage. Molecular mass standards to the left of the gel. 


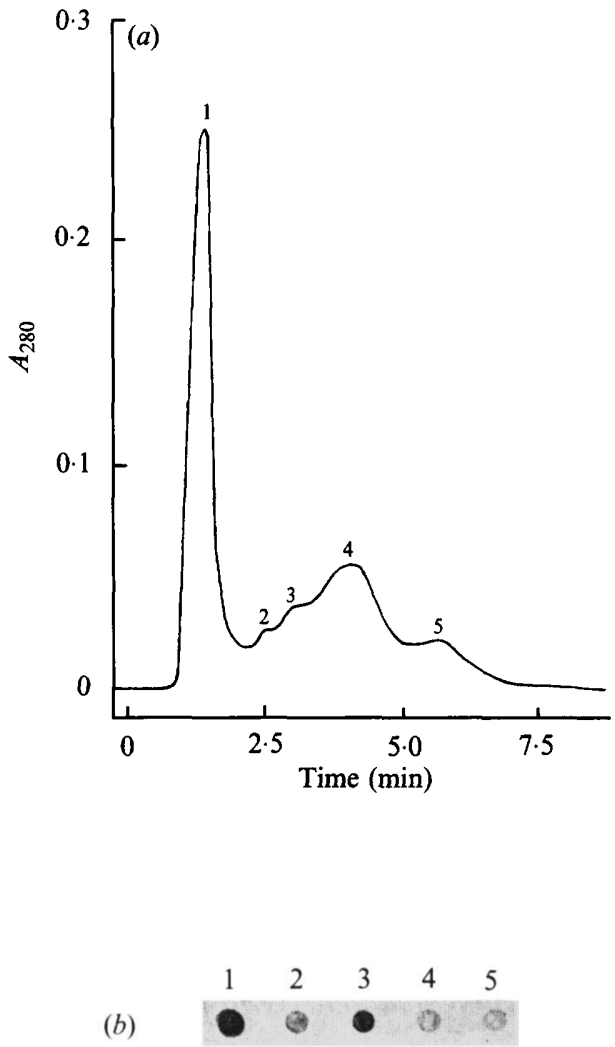

Fig. 5. Immunodot assay of desalted OSF. (a) Chromatogram of osmotic shock fluid desalted on a Fast Desalting Column HR 10/10. (b) Immunodot of fractions using anti-STb polyclonal antibodies. Numbers refer to collected fractions.

fractions were analysed by immunodot using anti-STb serum, peaks nos 1 and 3 were positive whereas peaks nos 2, 4 and 5 were negative (Fig. 5). The MBP-STb fusion protein, purified from the OSF by preparative electrophoresis and electroelution, was incubated with the Xa protease. Cleavage of MBP-STb yielded a peptide of approximately $5 \mathrm{kDa}$ that reacted with anti-STb serum (Fig. 4, lane 3).

\section{Discussion}

Various gene fusion systems have been described for expression and purification of STb enterotoxin to provide a source of immunogen and/or biologically active toxin (Spandau \& Lee, 1987; Handl et al., 1988; Lawrence et al., 1990; Urban et al., 1990a, 1991). However, many of the fusion proteins engineered showed little biological activity and/or the STb toxin could not be recovered from the hybrid protein.

Here we describe the genetic construction of a malEest $B$ gene fusion for overexpression of STb toxin. The expression and biological properties of the fusion protein were analysed. A MBP-STb fusion protein with a factor
$\mathrm{Xa}$ cleavage site at the serine 24 position of the $\mathrm{STb}$ precursor protein was produced (Lee et al., 1983; Picken et al., 1983; Kupersztoch et al., 1990). Restriction mapping and sequence analysis confirmed the presence and proper orientation of the entire est $B$ gene without its signal sequence.

One of the aims of this study was to overexpress the est $B$ gene. Spandau \& Lee (1987) showed that transcription of $\mathrm{STb}$ is regulated by a relatively weak constitutive promoter. Urban et al. (1990a) used a recombinant strain harbouring a cloned copy of the est $B$ gene and replaced the endogenous STb promoter with several highly active promoters such as bacteriophage $\mathrm{T} 7$ promoter and $\mathrm{P}_{\text {tac }}$. Construction of the hybrid plasmid named pMAL-STb, overexpressing STb enterotoxin, presents some advantages. The expression of MBP-STb is controlled by the strong, inducible $\mathrm{P}_{\mathrm{tac}}$ promoter. IPTG induction resulted in production of a MBP-STb fusion protein of $47 \mathrm{kDa}$, detectable in total cell extract and in osmotic shock fluid. The synthesized fusion protein remained cell-bound and was found in E. coli periplasm. A kinetic study of induction with IPTG revealed that $3 \mathrm{~h}$ after induction, the fusion product represented approximately $33 \%$ of OSF protein. This amount was not increased by longer incubation. In the absence of IPTG induction, the lacI repressor gene kept expression of the fusion low (Fig. $2 a$ lane 5). Recently, Aitken \& Hirst (1992) engineered a set of fusion proteins containing maltose-binding protein and heat-stable enterotoxin STa (MBP-STa) to generate solid-phase antigens that can be used to monitor anti-STa antibody response. Similarly to our results, they showed the fusion protein to be the most abundant single component found in the periplasm. Urban et al. (1990b) showed by ELISA that natural STb-producing strains produce little STb in defined-medium cultures relative to production by a recombinant strain harbouring a cloned copy of the $e s t B$ gene. Replacement of the endogenous STb promoter with several highly active promoters increased the yield of STb 10- to 20 -fold over that obtained by an E. coli strain harbouring the recombinant est $B$ gene, and correlated with intestinal secretory activity. Lawrence et al. (1990) cloned the STb gene in a high-expression vector $\mathrm{pKC} 30$ downstream from the strong $\mathrm{pL}$ promoter. They showed a 10- to 20-fold increase in messenger RNA of the strain containing the hybrid plasmid compared to a wild-type strain. However, there was little or no increase in enterotoxin activity as measured by the pig intestinal loop assay.

The MBP-STb protein can be easily purified from the OSF using preparative electrophoresis and electroelution. Moreover, the fusion protein can also be purified by affinity chromatography using amylose resin (data not shown). In pMAL-STb, the Xa site is at the 
junction between the MBP gene with its signal sequence and the gene for mature STb toxin. This protease cleaves specifically after a four amino acid recognition sequence (Fig. 1). The mature STb $5 \mathrm{kDa}$ toxin could be recovered after hydrolysis with factor $\mathrm{Xa}$.

Obtaining biologically active toxin was of prime importance as one of the purposes of this construct is to obtain STb toxin for elucidation of its mechanism of action. Handl et al. (1988) fused the est $B$ gene with the gene for protein $\mathrm{A}$, but the purified protein A-STb fusion had very low biological activity when tested in the pig intestinal loop assay, and the STb toxin could not be recovered from the fusion protein. Urban et al. (1990a) also produced a fusion protein between $\mathrm{STb}$ and alkaline phosphatase. This fusion protein induced intestinal secretion in a rat intestinal ligated loop assay. In these studies, the STb toxin was recovered as a fusion protein. In addition, there was no way to obtain the native toxin.

To examine the toxic property of the pMAL-STb fusion protein, crude OSF preparations from strain HB101 harbouring pMAL-STb were tested in the rat intestinal loop assay (Table 1). The OSF preparation was active in the biological model. In our study, STb was identifiable either by bioassay or as a band of approximately $5 \mathrm{kDa}$ either by silver staining or immunoblot after it was cleaved with factor Xa (Fig. 4). Thus, the STb moiety in the fusion protein was accessible to the anti-STb antibodies. In our study, OSF was biologically active, but intact MBP-STb molecules purified by gel filtration chromatography lacked enterotoxin activity (Fig. 5, peak 1). These results are in accordance with results published earlier by Handl et al. (1988) analysing the biological activity of protein A-STb in a pig intestinal loop assay. MBP-STb molecules are most probably spontaneously hydrolysed in OSF, and free $\mathrm{STb}$ molecules seem to be responsible for the biological activity of OSF in the rat intestinal loop assay. Thus, since MBP-STb has low biological activity as an intact molecule, the biological activity is likely to be associated with hydrolysed molecules. One possible explanation for the lack of activity of the fusion protein could be steric hindrance between the large carrier molecule and the low-molecular-mass toxin. More recently, a fusion protein between MalE and CD4, a specific receptor for HIV, (Clément et al., 1989; Szmelcman et al., 1990) was shown to be transported within the periplasm as expected. However, the hybrid protein was partially degraded even in a protease-minus background.

Immunization of animals is likely to evoke antibody responses to both proteins of the fusion. The maltosebinding protein of $E$. coli may be useful as a carrier molecule for the poorly immunogenic STb toxin (Dubreuil et al., 1991). The observation that the intact fusion protein possessed markedly reduced or no toxicity compared to altered (hydrolysed) molecules suggests that it could be used to induce an STb-neutralizing response. This possibility should be studied in more detail.

Since MBP-STb constitutes approximately $33 \%$ of the OSF total protein content for a yield of approximately 3-4 mg fusion protein per litre of induced culture, it is a promising way to obtain active STb in high quantity. However, this level of expression cannot be compared with that of the $E$. coli porcine strain used to purify STb (Dubreuil et al., 1991), since the yield was not evaluated in the latter case. To this day, the STb toxin has remained difficult to obtain in pure form from culture supernatants, not only because of its small size and sensitivity to proteolysis, but also because of the small amount of toxin recovered from culture supernatants of E. coli strains. The MBP-STb protein may provide a source of mature and biologically active STb toxin for determination of the toxin's mode of action.

This study was supported in part by grants from the Natural Sciences and Engineering Research Council of Canada (OGP0046569), from Fonds de la Recherche en Santé du Québec (Etablissement de Jeune Chercheur-901527) (to J.D.D.), from Fonds de la Recherche en Santé du Québec (Etablissement de Jeune Chercheur-870046) (to J.H.), from NSERC Strategic (STRG 117687) (to J.H. and J.D.D), from Stiftelsen till Emma och Erik Granes Minne and from Erik och Edit Fernströms Stiftelse för Medicinsk Forskning at the Karolinska Institute, Sweden (to C.H.). We thank Martine Caya for technical help with the rat intestinal loop assay and Charles Dozois for reviewing the manuscript.

\section{References}

Aitken, A. \& Hirst, T. R. (1992). Development of an immunoassay using recombinant maltose-binding protein-STa fusions for quantitating antibody responses against STa, the heat-stable enterotoxin of Escherichia coli. Journal of Clinical Microbiology 30, 732-734.

Betley, M. J., Miller, V. L. \& Mekalanos, J. J. (1986). Genetics of bacterial enterotoxins. Annual Review of Microbiology 40, 577-605.

Blake, M., Johnston, K. H., Russell-Jones, G. J. \& Gotschlich, E. C. (1984). A rapid, sensitive method for detection of alkaline phosphatase-conjugated anti-antibody on Western blots. Analytical Biochemistry 136, 175-179.

Burgess, M. N., Bywater, R. J., Cowley, C. M., Mullan, N. A. \& Newsome, P. M. (1978). Biological evaluation of a methanol-soluble, heat-stable Escherichia coli enterotoxin in infant mice, pigs, rabbits, and calves. Infection and Immunity 59, 198-203.

Clément, J.-M., Szmelcman, S., Jehanno, M., Martineau, P., SCHWARTZ, O. \& HofNUNG, M. (1989). Propriétés neutralisantes pour le virus HIV d'une protéine hybride MalE-CD4 exprimée chez Escherichia coli et purifiable en une étape. Compte Rendu Academie des Sciences (Paris) 308, 401-406.

Dubreuil, J. D., Fairbrother, J. M., Lallier, R. \& Larivière, S. (1991). Production and purification of heat-stable enterotoxin b from a porcine Escherichia coli strain. Infection and Immunity 58, 198-203.

Duplay, P., Bédouelle, H., Fowler, A., Zabin, I., Saurin, W. \& HoFNUNG, M. 1984. Sequences of the malE gene and of its product, the maltose-binding protein of Escherichia coli K12. Journal of Biological Chemistry 259, 10606-10613.

Fairbrother, J. M., Broes, A., Jacques, M. \& Larivière, S. (1989). 
Pathogenicity of Escherichia coli $0115: \mathrm{K}^{\prime} \mathrm{V} 165$ ' strains isolated from piglets with diarrhea. American Journal of Veterinary Research $\mathbf{5 0}$, 1029-1036.

Fuji, Y., Hayashi, M., Hitotshubashi, S., Fuke, Y., Yamanaka, H. \& OKAмото, K. (1991). Purification and characterization of Escherichia coli heat-stable enterotoxin II. Journal of Bacteriology 173, 5516-5522.

Handl, C., Rönnberg, B., Nilsson, B., Olsson, E., Jonsson, H. \& FLock, J. I. (1988). Enzyme-linked immunosorbent assay for Escherichia coli heat-stable enterotoxin type II. Journal of Clinical Microbiology 26, 1555-1560.

HandL, C. E., Olsson, E. \& Flock, J. I. (1992). Evaluation of 3 different STb assays and comparison of enterotoxin pattern over a five year period in Swedish porcine Escherichia coli. Diagnostic Microbiology and Infectious Diseases 15, 505-510.

Harel, J., Lapointe, H., Fallara, A., Lortie, L. A., Bigras-Poulin, M., LARIVIÈRE, S. \& FAIRBRother, J. M. (1991). Detection of genes for fimbrial antigens and enterotoxins associated with Escherichia coli serogroups isolated from pigs with diarrhea. Journal of Clinical Microbiology 29, 745-752.

HAWKES, R. (1982). Identification of concavalin A-binding proteins after sodium dodecyl sulfate-gel electrophoresis and protein blotting. Analytical Biochemistry 123, 143-146.

Hu, S. T., Yang, M. K., Spandau, D. F. \& Lee, C. H. (1987). Characterization of the terminal sequences flanking the transposon that carries the Escherichia coli enterotoxin ST II gene. Gene 55, 157-167.

Kupersztoch, Y. M., Tachias, K., Moomaw, C. R., Dreyfus, L. A., Urban, R. G., Slaughter, C. \& Whipp, S. (1990). Secretion of methanol-insoluble heat-stable enterotoxin (STb): energy- and secAdependent conversion of pre-STb to an intermediate indistinguishable from the extracellular toxin. Journal of Bacteriology 172, 2427-2432.

LAEMMLI, U. K. (1970). Cleavage of structural proteins during the assembly of the head of bacteriophage T4. Nature, London 227, 680-685.

Lawrence, R. M., Huang, P. T., Glick, J., Oppenheim, J. D. \& MAAS, W. K. (1990). Expression of the cloned gene for enterotoxin $\mathrm{STb}$ of Escherichia coli. Infection and Immunity 58, 970-977.

Lee, C. H., Moseley, S. L., Moon, H. W., Whipp, S. C., Gyles, C. L. \& So, M. (1983). Characterization of the gene encoding heat-stable toxin II and preliminary molecular epidemiological studies of enteropathogenic Escherichia coli heat-stable toxin II producers. Infection and Immunity 42, 264-268.

LORTí, L. A., DubreulL, J. D. \& HAREL, J. (1991a). Characterization of Escherichia coli strains producing heat-stable enterotoxin b (STb) isolated from humans with diarrhea. Journal of Clinical Microbiology 29, 656-659.

Lortí, L. A., Harel, J., Fairbrother, J. M. \& Dubreuil, J. D. $(1991 b)$. Evaluation of three new techniques for the detection of STb-positive Escherichia coli strains. Molecular and Cellular Probes 5, 271-275.

Lortí, L. A., Harel, J., Fairbrother, J. M. \& Dubreuil, J. D. (1991 c). Immunodot detection of Escherichia coli heat-stable enterotoxin $b$ by using enhanced chemiluminescence reaction. Journal of Clinical Microbiology 29, 2250-2252.

Maina, C. V., Riggs, P. D., Grandea, A. G. III, Slatko, B. E., Moran, L. S., Tagliamonte, J. A., McReynolds, L. A. \& Guan, C. (1988). A vector to express and purify foreign proteins in Escherichia coli by fusion to, and separation from maltose binding protein. Gene 74, 365-373.

Mainil, J. G., Moseley, S. L., Schneider, R. A., Sutch, K., Casey, T. A. \& Moon, H. W. (1986). Hybridization of bovine Escherichia coli isolates with gene probes for four enterotoxins $(\mathrm{STaP}, \mathrm{STaH}$, STb, LT) and one adhesion factor (K99). American Journal of Veterinary Research 47, 1145-1148.

Maniatis, T., FritsCh, E. F. \& SAmbrooK, J. (1982). Molecular Cloning: a Laboratory Manual. Cold Spring Harbor, NY: Cold Spring Harbor Laboratory.

Moon, H. W., SCHNEIDER, R. A. \& Moseley, S. L. (1986). Comparative prevalence of four enterotoxin genes among Escherichia coli isolated from swine. American Journal of Veterinary Research 47, 210-212.

Picken, R. N., Mazaitis, A. J., MaAs, W. K., Rey, M. \& Heyneker, H. (1983). Nucleotide sequence of the gene for heat stable enterotoxin II of Escherichia coli. Infection and Immunity 42, 269-275.

SACK, R. B. (1975). Human diarrheal disease caused by ETEC. Annual Review of Microbiology 29, 333-353.

So, M., Hefrron, F. \& McCarthy, B. J. (1979). The $E$. coli gene encoding heat-stable toxin is a bacterial transposon flanked by inverted repeats of IS1. Nature, London 277, 453-456.

So, M. \& MCCARTHY, B. J. (1980). Nucleotide sequence of the bacterial transposon Tn 1681 encoding a heat-stable (ST) toxin and its identification in enterotoxigenic Escherichia coli strains. Proceedings of the National Academy of Sciences of the United States of America 77, 4011-4015.

Spandau, D. F. \& LeE, C. H. (1987). Determination of the promoter strength of the gene encoding Escherichia coli heat-stable enterotoxin II. Journal of Bacteriology 169, 1740-1744.

Szmelcman, S., Clément, J. M., Jehanno, M., Schwartz, O., MontagnieR, L. \& Hofnung, M. (1990). Export and one-step purification from $E$. coli of a MalE-CD4 hybrid protein that neutralizes HIV1 in vitro. Journal of AIDS 3, 859-872.

Towbin, H., Staehelin, T. \& GoRdon, J. (1979). Electrophoretic transfer of proteins from polyacrylamide gels to nitrocellulose sheets: procedure and some applications. Proceedings of the National Academy of Sciences of the United States of America 74, 4350-4354.

Urban, R. G., Dreyfus, L. A. \& WhiPP, S. C. (1990a). Construction of a bifunctional Escherichia coli heat-stable enterotoxin (STb)alkaline phosphatase fusion protein. Infection and Immunity 58, 3645-3652.

Urban, R. G., Pipper, E. M., Dreyfus, L. A. \& WhipP, S. C. (1990 b). High-level production of Escherichia coli STb heat-stable enterotoxin and quantification by a direct enzyme-linked immunosorbent assay. Journal of Clinical Microbiology 28, 2383-2388.

Urban, R. G., Pipper, E. M. \& Dreyfus, L. A. (1991). Monoclonal antibodies specific for the Escherichia coli heat-stable enterotoxin STb. Journal of Clinical Microbiology 29, 1963-1968.

Weikel, C. S., Nellans, H. N. \& Guerrant, R. L. (1986). In vivo and in vitro effects of a novel enterotoxin, STb, produced by Escherichia coli. Journal of Infectious Diseases 153, 893-901. 